\title{
Yufid Kids Cartoon Media Effectiveness in Learning Arabic For Early Children
}

\author{
Chusniah Risnawati ${ }^{1}$, Imam Asrori ${ }^{2}$, M. Abdul Hamid ${ }^{3}$ \\ ${ }^{1}$ Universitas Islam Negeri Maulana Malik Ibrahim Malang, Indonesia \\ ${ }^{2}$ Universitas Negeri Malang, Indonesia \\ chusniah@gmail.com
}

\begin{abstract}
Education is one of the most important aspects in the formation of the development of human life. In practice there are many learning methods that can be used in conveying messages to a student, and one of the methods used in the process of educational development in early childhood is to using the animation media method, where in the learning process students also involve various additional media elements in it, animation learning media is a means of conveying information from the sender of the message to the recipient of the message, in the hope that the learning communication process can run effectively and the message is want to be conveyed can be accepted completely by children so that in the end it will improve children's language skills by involving elements of images and sounds. Where in this learning takes place and can attract the attention of students both in learning activeness, asking questions, and interacting. This can be seen from the positive attitudes of students seen during the learning process. This study uses a qualitative method approach by examining several literature studies related to the research objectives, namely to find out how to apply learning methods using cartoon animation media in improving Arabic for early childhood.
\end{abstract}

Keywords cartoon media; Arabic language learning; early childhood

\section{Introduction}

Education is a process of changing attitudes and behavior in a person or in a group of people, through which people can seek to change their mindset and perspective which is significant for themselves and for others (Yus, 2011). Education can also be interpreted as a learning experience that can be done anywhere, both in formal and non-formal contexts, but we often assume that the educational process is only found in schools, but in a broad view the educational process can occur in anywhere, in a family environment, community environment, and many other places for someone to get the optimal education possible starting from birth to the end of life, the narrow meaning, education is identical to schooling where education is carried out in the form of programmed and formally planned learning activities. Education can be interpreted as the process of changing the behavior of students so that they become adult humans who are able to live independently and as members of the community in the natural environment where the individual is located (Vega, 2016).

Education has meaning as a process in changing one's attitudes and behavior, education in a broad sense has meaning with certain methods so that people gain knowledge, understanding and how to behave according to their needs (Jailani, 2014). Along with the 
increasing advancement of technology and information, the educational process also adapts and follows the times, while experiencing progress both in the educational process and in supporting media, various efforts have been made and discussed in the process of improving education, and one of them is which occurs in the school environment, various educational management that occurs in the school environment has undergone many changes and improvements (Sudarsana, 2018).

Teachers as a medium for conveying various educational sciences do not escape the process of educational development, teachers are required to always improve their knowledge regarding concepts in the world of education. Because with a good process and planning, learning must certainly produce goals and achievements that can improve students' basic abilities in capturing the various learning methods that have been conveyed (Fadlillah, 2016). Learning objectives according to (Putra, 2016) can be classified into three, namely cognitive, affective and psychomotor. Cognitive aspects include continuous educational goals with memory or knowledge and thinking skills. The affective area includes educational goals with regard to interests, attitudes, and values.

Early childhood education is the level of education before the basic education level which is a coaching effort aimed at children aged 0-6 years which is carried out through providing educational stimuli to assist physical and spiritual growth and development so that children have readiness to enter further education, which held on formal, non-formal, and informal channels (Fitrhri, 2017). Improving the quality of education in schools is by improving the teaching and learning process. Various new concepts and insights about the teaching and learning process in schools have emerged and developed along with the rapid development of science and technology. Early childhood education aims to help lay the foundation for the development of attitudes, knowledge,

Early childhood is a child who is in the age range 0-8 years. Early childhood is also defined as a group of children who are in a unique process of growth and development. Early childhood learning / kindergarten is essentially play-oriented learning (learning while playing and playing while learning), development-oriented learning that gives more opportunities for children to be able to learn in appropriate ways. (Priyanto, 2014). They have a specific growth and development pattern according to the rate of growth and development. According to Law number 20 of 2003 concerning the national education system in Chapter 1 Article 1, point 14 that early childhood education is a coaching effort shown to children from birth to 6 years of age which is carried out through providing educational stimuli to assist physical and spiritual growth and development so that children have readiness to enter further education (Rahman, 2016) . At the Kindergarten level, children's development begins to be honed and developed through various basic training patterns where the goal is to improve the basic skills that can be shown by various trainings such as language development, in this one aspect of development, children will be trained. how can he show various stimuli through speech gestures.

According to Putri (2019) there are five stages of language development that are usually found in humans, including, phonology is a language sound system, then morphology is a rule for combining morphemes, which are a series of sounds which are the smallest unit of language, then syntax is a way words that are combined to form acceptable phrases and sentences, semantics is the meaning of the word or sentence, and the last is pragmatic where the use of appropriate conversation is.

In the growth period of early childhood, the importance of improving speaking skills is an aspect that can develop the potential and abilities of students where the child's ability will be very visible when he is able to show skills to interact well with his environment 
through good speaking and language skills, then at the next stage the child can express the ideas and feelings that exist in him and through fun activities the process will run quickly following the developmental pattern that is always applied gradually (Rahayu, 2018).

According to Resien (2020) learning is the process of changing behavior due to interactions among individuals and the environment. Changes in behavior include changes in knowledge, understanding, attitudes, skills, motivation, interests, thinking abilities and so on. Suparman in Sitorus (2019), argues that "learning is a process of behavior change that can be observed by others including by teachers". There are lots of methods that can improve the learning process, which can be applied to early childhood, one of which is by using media, and one of the media that can improve good language skills is animation media, one of the advantages of this method is where the child will quickly capture and explain the various learning that is displayed through images and also sound, animation or what is more commonly called an animated film or cartoon film is a film that is the result of managing still images to become a moving fanfare which is processed in an attractive form. ,especially in storytelling learning activities with the help of pictures and also sounds, children's interest in expressing various expressions that are generated from stimulation of the effects of animated media can accelerate memory and will affect the development of good and clear oral language skills, in addition to the ability to convey various children's stories will be trained to be more confident through the various vocabulary they get from the process of listening to images and also sounds generated from the learning method using animated media, according toBesides that, with the ability to convey various stories, children will be trained to be more confident through the various vocabulary they get from the process of listening to images and also sounds generated from the learning method with animated media, according toBesides that, with the ability to convey various stories, children will be trained to be more confident through the various vocabulary they get from the process of listening to images and also sounds generated from the learning method with animated media, according to(Uzer, 2019) argues that animation is one of the most interesting forms of pictorial presentation, in the form of a moving image simulation that describes the movement or movement of an object.

In the process of using this animation media, the learning process will feel very light because with the help of sound and images, the message conveyed will be very clear, and it is hoped that the children will be able to compensate for the system of applying these methods, because in addition to increasing effectiveness in The learning process of these methods is also very important to increase children's motivation and passion in the teaching and learning process (Fitriani, 2019). With the presence of various animated media that can increase the interest in learning of early childhood children, it is hoped that it can ease the task of a teacher in conveying the various messages he wants to convey to these children, the presence of animation media is also one of the most basic ways to share a variety of knowledge, experiences and the most important thing is to foster good interaction relationships between teachers and children (Zaini, 2017). Another advantage of this animation media is that children will not get bored easily with learning materials, considering that this process will always involve various images and audio which will always be updated every day with various themes and titles that are always different.

One of the most favorite animation media for children is cartoon media, with various images presented and the sound effects generated by cartoon media can be a solution for teachers in accelerating the process of delivering learning messages because of the benefits of the presence of media. This animation will be very influential and have a very positive impact on the growth and development of children, in other words, the presence of this animation method will provide new experiences and the process of 
learning activities in the classroom will vary greatly because it combines learning and playing processes. According to(Pransiska, 2013) the benefits of animated media include the learning process to be more interactive, the quality of teaching increases, the positive attitude of students towards what is learned can be improved, can change the positive role of teachers, and generate a will to action. The aims and objectives of this study are to find out how to apply learning methods using cartoon animation media in improving Arabic for early childhood.

As for some references and also previous research that researchers used in the preparation of this study are:

1. The Effectiveness of Animated Media on the Improvement of Students' Learning Outcomes in Making Women's ClothingIbu Kartini Junior High School Semarang, this research was compiled by (Astuti, 2016) using a qualitative descriptive research method, and the results of this previous study explained that there was an effective use of animation media to improve student learning outcomes. Learning media can also help teachers in delivering the material being taught and students can understand the subject matter. Learning media is used as a solution to solve problems experienced by students with the material presented by the teacher.

2. The Application of Animated Media in Improving the Language of Children Aged 5-6 Years in the Bela Bangsa Mandiri Tanjung Senang Kindergarten in Bandar Lampung, this research was compiled by (Helwanti, 2019) using The qualitative descriptive research method and the results of this previous research explain that the application of animation media in improving language in early childhood indirectly helps the role of the teacher in choosing the theme for the activity to be achieved, besides that the teacher also prepares the material as well as supporting tools when learning animation media will be carried out, and the most important thing is that the teacher provides material based on the principles of psychology and cognition and behavior in accordance with the abilities of these early childhood children.

3. The Use of Animated Media to Improve Social Emotional Ability in Early Childhood 5-6 Years In RA AL-MUTTAQIN, this research was compiled by (Siregar, 2017) using Classroom action research methods and the results of this previous research, show that through the use of animation media can increase the Social Emotional Ability of 5-6 years early childhood in RA Al-Muttaqin 2017/1018 before and after using animation media. In addition, the animation media learning method also has another impact on children's behavior such as helping friends, sharing, being polite to others, having a sense of responsibility.

\section{Research Methods}

In this study, the researcher wanted to study a phenomenon that discussed how the application of learning methods using cartoon animation media to improve Arabic for early childhood.In this study the researcher used a qualitative descriptive approach by reviewing several journals or articles related to the topic of using animation media. in improving the learning process for early childhood. There are two sources of data used in this study, where the data includes primary data as well as secondary data, which means secondary data is the main data related to the topic and also the research being studied. where researchers get these sources from journals and also references related to animation learning methods in improving the learning process for early childhood, while primary 
data is data that researchers find from observations and also findings in the field. The data collection method that researchers use in this study is to collect research data to determine the success or failure of a study. The data collection technique in this study is to use the observation method. Observation is a step taken by researchers by observing directly the symptoms in the field, make an observation and the most important thing from this observation stage is to take notes that are considered important so that it makes it easier for researchers to choose the information to use in the research (Setyosari, 2016). At the next stage in the qualitative research method the main objective of doing data analysis techniques is to lighten the data and facts that have been found in the field in a form that is easier to understand or the data is summarized and summarized more easily to interpret. so that the relationship problems that occur between the research that is being done can be studied easily (Lain, 2013).

\section{Discussion}

Based on the results of the research that has been carried out, using the observation method of several articles related to the topic of discussing the application of learning methods using animation media for early childhood and by evaluating and also analyzing data on findings in the field, it can be concluded that several results and also a careful discussion found, namely:

\subsection{The Use of Cartoon Animation Media in Increasing Interest in Learning in Early Childhood}

The process of teaching and learning activities certainly cannot be separated from various supporting aspects in it as well as learning methods that involve animation media as a form to stimulate students to quickly capture various understandings and also messages conveyed by a teacher, the role of animation media in the learning process. Of course, it has a very significant impact, especially in shaping characters and creating very different classrooms, the use of animated media can also help a teacher's task when it cannot represent the messages conveyed through words or sentences (Trina, 2017).The effectiveness of children's absorption will also be quickly obtained through the animation media aids because in the process it involves various media that present images and sounds that can attract children's interest and enthusiasm in participating in teaching and learning activities, the aids can excite the enthusiasm for learning. students who will later have an impact on the learning outcomes of students (Sukiyasa, 2013.) by maximizing the various cartoon characters that children at that age really enjoy doing, the learning process will feel light and will not give the impression of being bored and the children are not burdened with the materials and learning methods they are running,Besides that, the use of animation media must also meet the requirements where in practice this method must provide multiple motivation to learn to children because the effect of this method must provide feedback or responses in accordance with the expectations of students.

\subsection{The Effectiveness and Impact of Learning Methods Using Cartoon Animation Media on Early Childhood Learning Interest}

In addition, learning media should also be used as a solution that is used by a teacher when there are obstacles and also problems when one of the students has difficulty receiving the learning material that is conveyed (Tresna, 2017). Another impact that is felt by the existence of the animation media learning method is the increased creativity shown 
by children with the help of this method, because children will always be required to always move actively and try to conclude the message that is presented through various pictures and audio visual. The role of animation media can also increase various understandings which of course make it easier for children to get information about subjects and learning methods.

According to Salamun (2020) practical benefits of developing image media in the learning process are as follows, image media can clarify the presentation of messages and information so that it can facilitate and improve the learning process, image media can also increase and direct children's attention so that it can lead to multiple learning motivation double, image media can overcome the limitations of time and space senses, and another function of image media is to provide students with similar experiences and perceptions.

Of course there will be lots of positive impacts arising from the application of learning patterns using animation media, because with the presence of animated media objects or objects that are too large to be displayed directly in the classroom can be replaced with image media, and vice versa. those that are too small can be seen clearly through the medium of animation media, animation media can also show various incidents of events that have occurred in the past and in the future, with the growing technological capabilities of animation media can show them and be applied in learning patterns according to the abilities and interests of early childhood,In addition, animation media can show objects or processes that are considered very complicated and through the help of animation media, the process can be described in a concrete manner and of course makes it easier for children to conclude various events through these animated images.

\subsection{Animated Media Learning Methods as Language Development for Early Childhood}

Language development through animation media is one way to assist children in interacting directly with their social environment, because the more fluent the child speaks, the faster the child can form his own character and convey the various feelings he feels. The use of animated media in the learning process can also stimulate the understanding of early childhood in concluding various messages through the form of images and audio visuals, Setyorini (2015) said that learning media as information-carrying technology that can be used for the teaching and learning process, meanwhile (Romi , 2020) also stated that, media is a type of component in the student environment that can stimulate learning. In early childhood development,

According to Helmanto (2020) the language that children have and control is a language that develops in the family, which we often refer to as the Mother Language. Dickinson in Wasik argues that to learn languages, children need opportunities to speak and be heard. Teachers and adults must respond to the child who is talking, ask questions that encourage the child to talk more, expand and cultivate what the child is saying.

With the application of the learning method using animation, it is hoped that the children will quickly hone and understand the various meanings of speech that are produced from the various images and audio-visuals that are presented, because indirectly the process of language formation through animation media will also develop the vocabulary in the children have, because the more language is spoken, it is hoped that children will be able to compose these words into simple sentences. The function of language for early childhood is as a tool to develop children's intellectual abilities and basic abilities (Afiyuddin , 2017).

In particular, Gardner argues that the function of language for early childhood is to be a tool for communicating with the environment, as a tool to develop children's 
intellectual abilities, as a tool for developing children's expressions to explore Arabic language skills.

The development of the process of language formation through animation media includes various aspects in it, where the pattern will form the characteristics of early childhood, including development when the child is writing, speaking, and reading, because at that stage children's language skills will be very visible, with the encouragement of animated media The process will run quickly, when the child starts to get used to speaking various vocabulary words that he trains through animation media, the child should be able to pronounce more than 2,500 syllables, be able to communicate clearly with the environment besides that the child is able to recognize various colors well and able to participate in an Arabic conversation (Wijaksono, 2020).

\section{Conclusion}

Based on the research that the researchers conducted on the application of learning methods using cartoon animation media in improving Arabic for early childhood, the researchers can conclude several main points that can be drawn conclusions, the results of various observations that the researchers found in the field, namely:

1 The use of animation media in an early childhood school environment can help the learning process that is displayed with various images and sounds by involving supporting elements in the process of forming a good and fast learning system with the aim of the process being clearly understood by children.

2 In the process, the formation of learning patterns by involving animation media will greatly assist students in conveying various messages to early childhood because the presence of these learning patterns will make it easier for students to process and convey these messages in detail and clearly.

3 The use of animation media will also have a very real impact on early childhood development because in addition to honing children's motor skills, these patterns can also improve language skills which are very helpful for the child's developmental patterns.

4 Animated media can also generate new ideas and ideas so that children are more confident and always develop the potential they have in themselves.

5 Animated media learning patterns can also make it easier for students to plan various preparations that will be applied to early childhood.

6 Animated learning media can also increase the activeness of students in providing responses, feedback and also encourage students to carry out practices outside the school environment.

7 The application of animation media can also be one of the modes of approach in the learning process because in this method children will be trained with various approaches, one of which is to train the catch or concentration power of early childhood, besides that this process can also train children's thinking and develop speaking skills, increase language vocabulary and create a different atmosphere in the classroom because it combines the concept of learning while playing. 


\section{References}

Afiyuddin, M. I. (2017). Pembuatan Animasi 2D sebagai Media Pembelajaran Bahasa Arab pada Materi Bagian Luar Tubuh Manusia dengan Metode SAV (Doctoral dissertation, Sekolah Tinggi Elektronika dan Komputer Semarang).

Astuti, D. (2016). Efektivitas Media Animasi terhadap Peningkatan Hasil Belajar Membuat Busana Wanita Siswa Smk Ibu Kartini Semarang (Doctoral dissertation, Universitas Negeri Semarang).

Fadlillah, M. (2016). Edutainment Pendidikan Anak Usia Dini: Menciptakan Pembelajaran Menarik, Kreatif dan Menyenangkan. Prenada Media.

Fithri, D. L., \& Setiawan, D. A. (2017). Analisa Dan Perancangan Game Edukasi Sebagai Motivasi Belajar Untuk Anak Usia Dini. Simetris: Jurnal Teknik Mesin, Elektro dan Ilmu Komputer, 8(1), 225-230.

Fitriani, D., Fajriah, H., \& Rahmita, W. (2019). Media Belajar Big Book dalam Mengembangkan Kemampuan Berbahasa Reseptif Anak Usia Dini. Jurnal Obsesi: Jurnal Pendidikan Anak Usia Dini, 4(1), 237-246.

Helmanto, F. (2020). Flashcard: Belajar Mufrodat Bahasa Arab Semakin Menantang. Tatsqifiy: Jurnal Pendidikan Bahasa Arab, 1(2), 141-151.

Helwanti, J. (2019). Penerapan Media Animasi dalam Meningkatkan Bahasa Anak pada Usia 5-6 Tahun di Taman Kanak-Kanak Bela Bangsa Mandiri Tanjung Senang Bandar Lampung (Doctoral Dissertation, UIN Raden Intan Lampung).

Irsa, D., Saputra, R. W., \& Primaini, S. (2016). Perancangan aplikasi game edukasi pembelajaran anak usia dini menggunakan linear congruent method (LCM) berbasis android. Jurnal Informatika Global, 6(1).

Jailani, M. S. (2014). Teori Pendidikan Keluarga dan Tanggung Jawab Orang Tua dalam Pendidikan Anak Usia Dini. Nadwa, 8(2), 245-260.

Lain, J. (2013). Penelitian pendidikan. Jurnal Lain, 13(1).

Setyosari, H. P. (2016). Metode penelitian pendidikan \& pengembangan. Prenada Media.

Panggayudi, D. S. (2017). Media game edukasi berbasis budaya untuk pembelajaran pengenalan bilangan pada anak usia dini. MUST: Journal of Mathematics Education, Science and Technology, 2(2), 255-266.

Pransiska, R. (2013). Pemanfaatan IT Sebagai Media dalam Mengenalkan Bahasa Ingris pada Pendidikan Anak Usia Dini. Pedagogi: Jurnal Ilmu Pendidikan, 13(2), 107-112.

Putra, D. W., Nugroho, A. P., \& Puspitarini, E. W. (2016). Game Edukasi berbasis android sebagai media pembelajaran untuk anak usia dini. JIMP-Jurnal Informatika Merdeka Pasuruan, 1(1).

Putri, D. A. P. (2019). Rancang Bangun Media Pembelajaran Bahasa Arab Untuk Anak Usia Dini Berbasis Android. Technologia: Jurnal Ilmiah, 10(3), 156-164.

Rahayu, S. L., \& Fujiati, F. (2018). Penerapan Game Design Document dalam Perancangan Game Edukasi yang Interaktif untuk Menarik Minat Siswa dalam Belajar Bahasa Inggris. Jurnal Teknologi Informasi dan Ilmu Komputer, 5(3), 341-346.

Rahman, R. A., \& Tresnawati, D. (2016). Pengembangan game edukasi pengenalan nama hewan dan habitatnya dalam 3 bahasa sebagai media pembelajaran berbasis multimedia. Jurnal Algoritma, 13(1), 184-190.

Resien, Sitompul, H., and Situmorang, H. (2020). The Effect of Blended Learning Strategy and Creative Thinking of Students on the Results of Learning Information and Communication Technology by Controlling Prior Knowledge. Budapest 
International Research and Critics in Linguistics and Education (BirLE) Journal Vol 3 (2): 879-893.

Romi, Y. F. S., Rahmawati, N., \& Amrullah, N. A. (2020). Mabar: Pengembangan Media Pembelajaran Berbasis Adobe Flash Professional Cs 6 Untuk Keterampilan Menyimak Bahasa Arab Kelas VIII MTS. Lisan Al-Arab: Journal of Arabic Language And Arabic Teaching, 9(1), 80-85.

Salamun, S. N. (2020). Pengembangan Media Pembelajaran Interaktif Berbasis Video Animasi Bahasa Arab di MTs. N 1 Maluku Tenggara (Doctoral dissertation, Universitas Muhammadiyah Malang).

Setyorini, I. (2015). Animasi Interaktif Kosakata Dalam Dua Bahasa (Arab-Inggris) Pada RA Kuwait Pusdiklat Dewan Da'wah Bekasi. Bina Insani ICT Journal, 2(2), 85-100.

Siregar, H. (2017). Penggunaan Media Animasi Untuk Meningkatkan Kemampuan Sosial Emosional Pada Anak Usia Dini 5-6 Tahun Di RA Al-Muttaqin 2017/2018 (Doctoral dissertation, Universitas Islam Negeri Sumatera Utara Medan).

Sitorus, H. (2019). The Effect of Learning Strategy and Thinking Ability on The Students' Learning Outcomes in Economics Subject of XI Social Students in Senior High School State 1 in Pematang Siantar. Budapest International Research and Critics in Linguistics and Education (BirLE) Journal. p. 451-460.

Sudarsana, I. K. (2018). Membentuk Karakter Anak Sebagai Generasi Penerus Bangsa Melalui Pendidikan Anak Usia Dini. Purwadita: Jurnal Agama dan Budaya, 1(1).

Sukiyasa, K., \& Sukoco, S. (2013). Pengaruh media animasi terhadap hasil belajar dan motivasi belajar siswa materi sistem kelistrikan otomotif. Jurnal Pendidikan Vokasi, 3(1).

Tresnawati, D., \& Rizqi, R. F. (2017). Rancang Bangun Aplikasi Pengenalan Dasar Bahasa Arab Sebagai Media Pembelajaran Berbasis Android. Jurnal Algoritma, 14(2), 314322.

Trina, Z., Kamaruddin, T., \& Purnomowati, D. R. (2017). Penerapan Media Animasi Audio Visual Menggunakan Software Powtoon Untuk Meningkatkan Hasil Belajar IPS SMP Negeri 16 Banda Aceh. Jurnal Ilmiah Mahasiswa Pendidikan Geografi, 2(2).

Uzer, Y. V. (2019). Strategi belajar bahasa inggris yang menyenangkan untuk pendidikan anak usia dini. PERNIK Jurnal PAUD, 2(1).

Vega Vitianingsih, A. (2016). Game edukasi sebagai media pembelajaran pendidikan anak usia dini. Inform, 1(1), 25-32.

Wijaksono, A. (2020). Pengembangan Bahan Ajar Bahasa Arab Berbasis Aplikasi Android. At-Turost: Journal of Islamic Studies, 7(2), 165-185.

Yus, A. (2011). Model pendidikan anak usia dini. Kencana.

Zaini, H., \& Dewi, K. (2017). Pentingnya media pembelajaran untuk anak usia dini. Raudhatul Athfal: Jurnal Pendidikan Islam Anak Usia Dini, 1(1), 81-96. 